\title{
Pengaruh Penggunaan Program Computer Assisted Instruction (CAI) Terhadap Hasil Belajar IPA
}

\author{
Yudi Hermawan \\ (Program studi Pendidikan Guru Sekolah Dasar, Fakultas Ilmu Pendidikan Universitas MH. Thamrin)
}

\begin{abstract}
ABSTRAK
Pengaruh Penggunaan Program Computer Assisted Instruction (CAI) terhadap Hasil Belajar IPA. Penelitian ini menggunakan metode eksperimen. Tujuan penelitian ini adalah untuk menganalisis pengaruh penggunaan CAI terhadap hasil belajar IPA pada materi sifat bahan dan perubahan benda. Penelitian menggunakan sampel yang diambil dengan menggunakan teknik Klaster Random Sampling. Pengumpulan data dilakukan dengan menggunakan tes hasil belajar IPA dengan materi sifat bahan dan perubahan benda, kemudian dihitung normalitas data menggunakan liliefors dan homogenitas kelas menggunakan uji F. Hasil pengujian normalitas dan homogenitas menunjukkan bahwa data berdistribusi normal dan kedua kelas tidak homogen. Selanjutnya dianalisa dengan uji t. Hasil penghitungan uji-t, diperoleh harga thitung sebesar 3.56. Harga tabel pada taraf signifikansi $\alpha=0,05$ dan $d k=34$ adalah 1,70. Oleh karena harga thitung lebih besar daripada t tabel (2,26 > 1,70), maka hipotesis nol ditolak dan hipotesis kerja diterima. Dengan demikian, program CAI berpengaruh secara signifikan terhadap hasil belajar IPA pada materi sifat bahan dan perubahan benda.
\end{abstract}

Kata kunci : (CAI), Hasil Belajar IPA, Metode Eksperimen, Klaster Random Sampling 


\section{Pendahuluan}

IPA merupakan mata pelajaran penting yang menjadi pengetahuan dasar kemajuan teknologi. IPA mempelajari tentang berbagai gejala alam, yang bersifat analitis, logis, rasional, lengkap dan cermat yang berupa prinsip-prinsip, teori-teori, hukum-hukum, konsep-konsep, maupun fakta-fakta yang ditunjukkan untuk menjelaskan gejala-gejala alam sehingga membentuk suatu sudut pandang yang baru terhadap objek yang diamatinya. Seseorang yang telah belajar IPA akan memperlihatkan perubahan tingkah laku dalam memahami berbagai gejala alam. Ia akan menemukan fakta-fakta di alam sekitarnya berdasarkan sikap ilmiah sebagai hasil proses belajar IPA.

Mengingat pentingnya mata pelajaran IPA, maka sistem pembelajarannya harus kreatif dan menarik agar pembelajaran IPA tidak membosankan bagi siswa. Guru yang baik harus mampu menerapkan pembelajaran yang sesuai dengan karakteristik siswa. Siswa pada usia sekolah dasar umumnya senang bermain, bergerak dan senang melakukan sesuatu secara langsung. Mereka lebih senang memikirkan halhal yang konkret daripada yang abstrak. Karakteristik utama siswa sekolah dasar adalah mereka menampilkan perbedaan-perbedaan individual dalam banyak segi dan bidang, diantaranya, perbedaan dalam intelegensi, kemampuan dalam kognitif dan bahasa, perkembangan kepribadian dan perkembangan fisik anak.

Pembelajaran IPA berbantuan komputer merupakan salah satu metode pembelajaran yang dapat dijadikan pertimbangan dalam memilih metode pembelajaran IPA. Pembelajaran IPA berbantuan komputer atau yang disebut Computer Assisted Instruction (CAI) adalah salah satu bentuk metode pembelajaran yang disesuaikan dengan kurikulum sekolah dan ditunjang dengan alat-alat teknologi. Penggunaan komputer dalam pembelajaran akan mengenalkan siswa tentang kemajuan teknologi, sehingga siswa tidak tertinggal oleh kemajuan zaman.

Pembelajaran dengan metode Computer Assisted Instruction (CAI) memberikan kesempatan bagi siswa untuk bereksperimen sehingga mampu memberikan kondisi belajar yang dapat mengembangkan kemampuan berpikir dan kreativitas secara optimal. Siswa memanipulasi sendiri media pembelajaran yang disediakan. Siswa belajar secara aktif dengan mengikuti tahap-tahap pembelajaran sehingga siswa akan menemukan sendiri konsep-konsep yang disampaikan melalui media pembelajaran. Hal ini sesuai dengan karakterisik siswa sekolah dasar yang cenderung aktif dan senang bermain.

Program-program pembelajaran IPA yang berbantuan komputer atau Computer Assisted Instruction (CAI) sudah banyak ditemukan di pasaran. Program-program tersebut dikenal dengan istilah software. Pada umumnya program-program tersebut bersifat edutaiment (education and entertaiment). Tujuannya adalah agar siswa merasa tertarik pada materi pelajaran yang disampaikan dan tidak mudah jenuh dalam belajar. Dengan begitu materi pembelajaran akan mudah terserap oleh siswa dan proses pembelajarannya menjadi lebih bermakna.

\section{Metode Penelitian}

Metode yang digunakan adalah penelitian eksperimen yang dimaksudkan untuk mengetahui pengaruh penggunaan Computer Assisted Instruction (CAI) dengan model pembelajaran melalui media Audio Visual.

Adapun desain penelitian yang digunakan adalah eksperimen bentuk Postest-Only Equivalent-Group Design. Seperti terlihat pada bagan berikut:

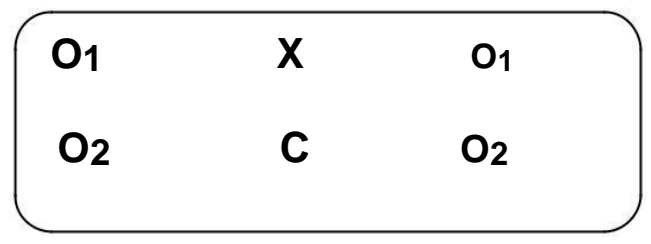

Postest-Only Equivalent-Group Design 


\section{Keterangan:}

$\mathrm{O}_{1}=$ Observasi pada kelas eksperimen

$\mathrm{O}_{2} \quad=$ Observasi pada kelompok kontrol/ pembanding

$\mathrm{X}=$ Perlakuan treatment pada kelompok eksperimen

$\mathrm{C}=$ Placebo (seolah perlakuan) pada kelompok kontrol

\section{Populasi dan Teknik Pengambilan Sampel}

Populasi target dalam penelitian ini adalah semua siswa kelas V Sekolah Dasar Negeri Mekarsari Tambun Selatan Bekasi Timur tahun ajaran 2011/2012. Populasi terjangkau pada penelitian ini adalah siswa kelas V paralel SDN Mekarsari Tambun Selatan Bekasi Timur, terdiri dari kelas V A dan V B yaitu SDN Mekarsari 01, 02, 03, 04, 05, 06, 07, 08 dan 09. Teknik pengambilan sampel yang digunakan adalah (Klaster Random Sampling) yaitu pengambilan sampel berdasarkan kelompok (sekolah). Pemilihan sampel dimulai dengan melakukan pengelompokan sekolah yang ada di Gugus V SDN Mekarsari terdiri dari 9 klaster (sekolah) sebagai berikut: 01, 02, 03, 04, 05, 06, 07, 08 dan 09. Berdasarkan klaster tersebut dilakukan pengambilan sekolah yang dilakukan secara random melalui undian maka terpilihlah SDN Mekarsari 06 sebagai tempat penelitian. Di sekolah tersebut terdapat 70 siswa kelas $\mathrm{V}$ yang terbagi ke dalam 2 kelas, yaitu kelas V A yang terdiri dari 35 siswa dan kelas V B yang terdiri dari 35 siswa. Kelas V A sebagai kelas eksperimen dan kelas V B sebagai kelas kontrol.

\section{Instrument Penelitian}

Instrumen berbentuk soal pilihan ganda dengan 4 pilihan jawaban. Jawaban yang benar diberi skor 1 dan jawaban yang salah diberi skor 0 .

\section{Pengujian Instrumen}

1. Uji Validasi: pengujian validitas data dikotomi dengan cara korelasi biserial yaitu dengan mengkorelasikan setiap butir dengan butir total.

2. Uji Tingkat Kesukaran: pengujian tingkat kesukaran butir soal.

3. Uji Daya Beda: menguji tingkat perbedaan butir soal.

4. Uji reliabilitas : pengujian reliabelitas penelitian ini adalah rumus Kuder-Richardson number 20 (KR20).

\section{Instrumen Final}

Tes ini menggunakan tes pilihan ganda dengan jumlah 30 soal. Skor tiap butir 1 bila benar dan 0 bila salah. Untuk menentukan nilai masing-masing individu siswa dilakukan dengan cara sebagai berikut:

Nilai = Jumlah jawaban benar / bobot soal (30) x 100 Misalnya: siswa menjawab benar 20 salah sepuluh maka nilainya $=20 / 30 \times 100=67$.

\section{Analisis Data Statistik}

Data yang terkumpul melalui penelitian ini dianalisis dengan menggunakan teknik statistika.

\section{Uji Persyaratan Normalitas}

Pengujian normalitas dilakukan untuk menguji data tersebut normal atau tidak. Dalam penelitian ini untuk menguji normalitas menggunakan liliefors. Apabila hasil perhitungan dengan liliefors (Lhitung) lebih kecil dari (Ltabel), maka data tersebut berdistribusi normal.

\section{Uji Homogenitas}

Di samping pengujian terhadap normal tidaknya distribusi data pada sampel, juga perlu dilakukan pengujian terhadap kesamaan (homogeny) beberapa bagian sampel, yaitu seragam tidaknya sampel yang diambil dari populasi yang sama. Dalam penelitian ini perhitungan homogenitas menggunakan uji beda dua varians, dengan rumus $\mathrm{F}=$ Varian terbesar/varian terkecil. Kriteria pengujian, bila Fhitung $<$ Ftabel maka data sampel diperoleh dari populasi berdistribusi homogeny. 


\section{Hasil Penelitian}

Data penelitian ini diperoleh dari 35 orang siswa, dengan mengukur hasil belajar IPA siswa kelas V (Y) yang menggunakan Program Computer Assisted Instruction (CAI) dalam sifat bahan dan perubahan benda. Data dasar hasil penelitian dideskripsikan untuk memperoleh gambaran tentang hasil belajar siswa dalam pelajaran IPA yang menggunakan Program Computer Assisted Instruction (CAI).

1. Hasil Belajar IPA Sebelum Menggunakan Program Computer Assisted Instruction (CAI) pada Kelas Eksperimen.

Skor hasil belajar IPA diperoleh dengan menghitung skor yang diperoleh setelah merata-ratakan hasil belajar IPA sebelum menggunakan Program Computer Assisted Instruction (CAI). Skor diperoleh dengan menghitung hasil belajar siswa setelah menyelesaikan tes yang diberikan guru. Dari hasil skoring diperoleh rentang data secara empiris 0 - 100. Skor empiris terendah adalah 43 dan skor teringgi 77. Rata-rata skor adalah 58,48, dan simpangan baku 7,86.

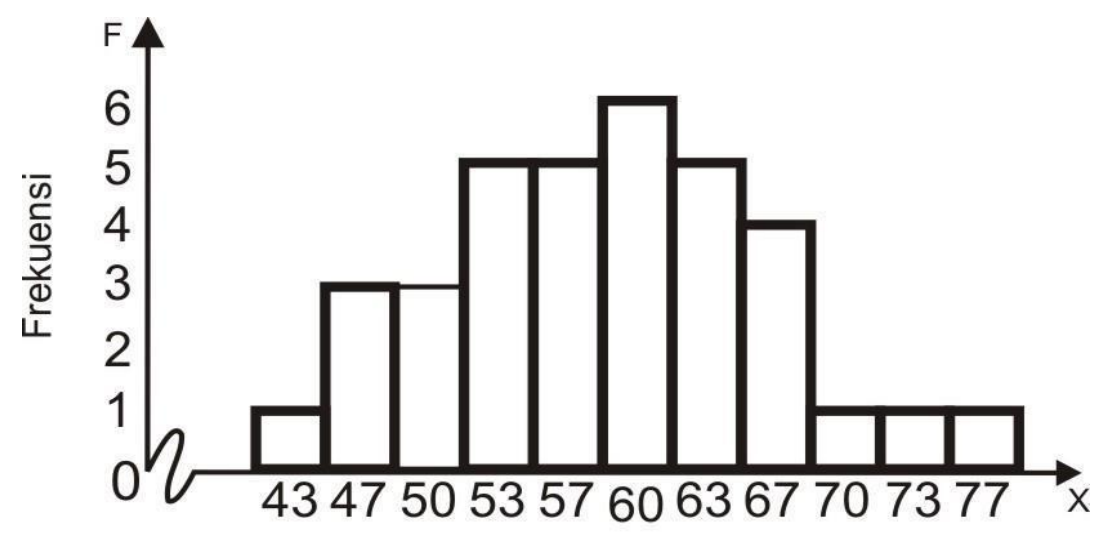

\section{Nilai \\ Diagram Batang Variabel Hasil Belajar IPA Sebelum Menggunakan Program Computer Assisted Instruction (CAI)}

\section{Hasil Belajar IPA Sesudah menggunakan Program Computer Assisted Instruction (CAI) Kelas} Eksperimen

Skor hasil belajar IPA diperoleh dengan menghitung skor yang diperoleh setelah merata-ratakan hasil belajar IPA sesudah menggunakan Program Computer Assisted Instruction (CAI). Skor diperoleh dengan menghitung hasil belajar siswa setelah menyelesaikan tes yang diberikan guru. Dari hasil skoring diperoleh rentang data secara teoritis $0-100$. Skor empiris terendah adalah 57 dan skor teringgi 90. Rata-rata skor adalah 71,6 dan simpangan baku 7,59.

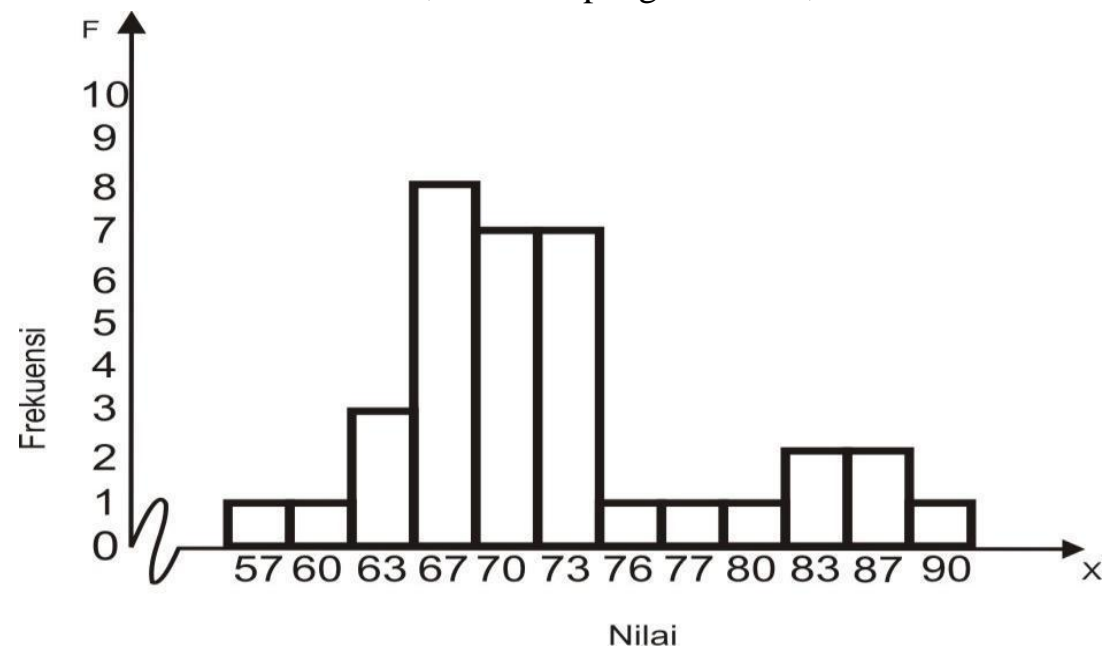




\section{Hasil Belajar IPA Sebelum Menggunakan Media Audio Visual Kelas Kontrol}

Skor hasil belajar IPA diperoleh dengan menghitung skor yang diperoleh setelah merata-ratakan hasil belajar IPA sebelum menggunakan Media Audio Visual. Skor diperoleh dengan menghitung hasil belajar siswa setelah menyelesaikan tes yang diberikan guru. Dari hasil skoring diperoleh rentang data secara teoritis $0-100$. Skor empiris terendah adalah 33 dan skor teringgi 70. Rata-rata skor adalah 53,45 dan simpangan baku 10,52.

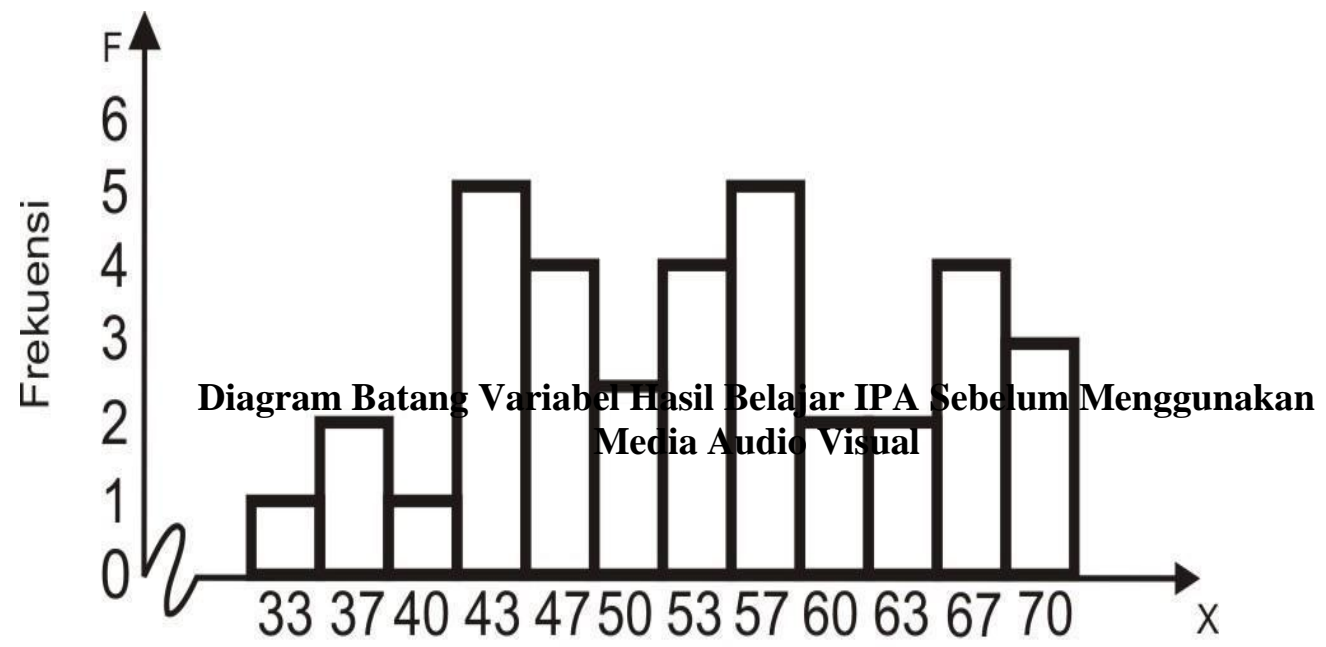

Nilai

\section{Hasil Belajar IPA Sesudah Menggunakan Media Audio Visual Kelas Kontrol}

Skor hasil belajar IPA diperoleh dengan menghitung skor yang diperoleh setelah merata-ratakan hasil belajar IPA sesudah menggunakan Media Audio Visual. Skor diperoleh dengan menghitung hasil belajar siswa setelah menyelesaikan tes yang diberikan guru. Dari hasil skoring diperoleh rentang data secara teoritis $0-100$. Skor empiris terendah adalah 43 dan skor teringgi 83. Rata-rata skor adalah 63,28 dan simpangan baku 10,38.

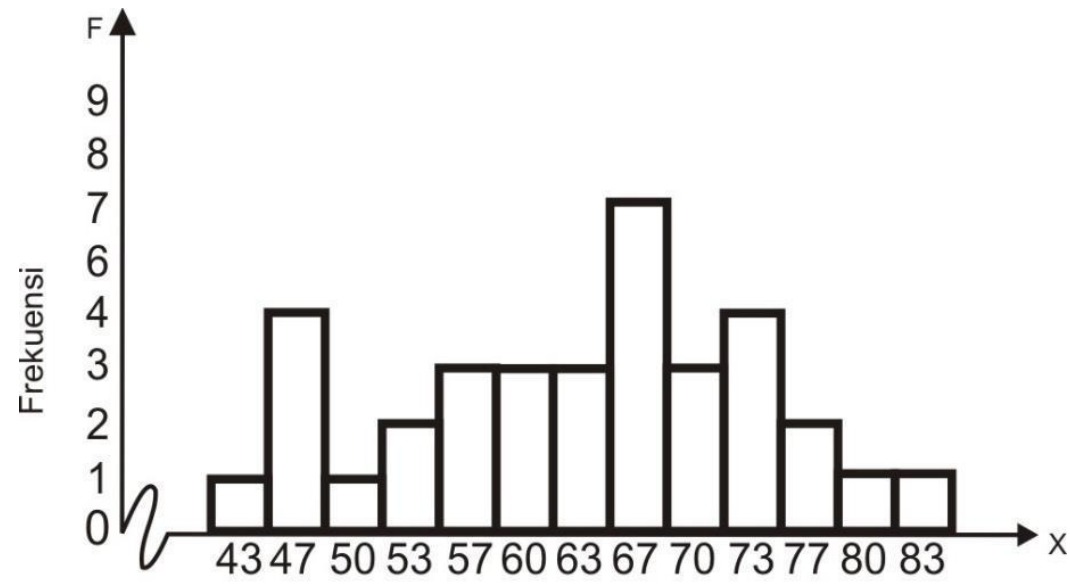

\footnotetext{
Nilai

Diagram Batang Variabel Hasil Belajar Matematika Sesudah Menggunakan Media Audio Visual
} 


\section{Pengujian Persyaratan Analisis}

\section{Uji Normalitas}

Uji normalitas hasil belajar matematika dilakukan dengan menggunakan liliefors. Harga Ltabel pada taraf signifikansi $\alpha=0,05$ untuk $\mathrm{n}=35$ adalah 0,150 , dan karena keempat harga Lhitung pada hasil pengujian normalitas tersebut lebih kecil dari Ltabel $(0,097,0,123,0,100$, dan 0,083), maka dapat disimpulkan bahwa data pada kelas eksperimen maupun kelas kontrol berdistribusi normal.

\section{Uji Homogenitas}

Berdasarkan hasil perhitungan menggunakan uji beda dua varians, uji - F diperoleh Fhitung sebesar 1,87 , sedangkan $F_{\text {tabel }}$ pada derajat kebebasan penyebut 34 dan derajat kebebasan pembilang 34 pada taraf $\alpha 0.05$ diperoleh $\mathrm{F}$ tabel sebesar 1,76. Ternyata Fhitung lebih besar dari pada Ftabel maka kedua data tidak berdistribusi homogeny.

\section{Uji Hipotesis}

Berdasarkan hasil penghitungan uji-t, diperoleh harga thitung sebesar $3.56 \mathrm{dan} \mathrm{dk}=34$, sedangkan harga tabel pada taraf signifikansi $\alpha=0,05 \mathrm{dan} \mathrm{dk}=34$ adalah sebesar 1,70. Oleh karena harga thitung lebih besar daripada tabel $(3,56>1,70)$, maka artinya hipotesis nol $\left(\mathrm{H}_{0}\right)$ ditolak dan hipotesis kerja $\left(\mathrm{H}_{1}\right)$ diterima.

Berdasarkan hasil pengujian tersebut di atas Program Computer Assisted Intruction (CAI) berpengaruh secara positif terhadap hasil belajar IPA tentang sifat benda dan perubahannya dibandingkan metode Audio Visual pada kelas V SDN Mekarsari 06. Hal ini terbukti bahwa thitung > tabel.

Setelah dilakukan pengujian hipotesis, diperoleh hasil bahwa hipotesis nol $\left(\mathrm{H}_{0}\right)$ yang menyatakan tidak ada pengaruh yang signifikan dari penggunaan Media Audio Visual terhadap hasil belajar IPA pada siswa kelas V SD ditolak. Oleh karena hipotesis nol ditolak maka dapat disimpulkan bahwa ada pengaruh yang signifikan dari penggunaan Program Computer Assisted Instruction (CAI) terhadap hasil belajar IPA siswa kelas V SD. Artinya hipotesis kerja $\left(\mathrm{H}_{1}\right)$ diterima.

Selain diterimanya hipotesis kerja, hasil penelitian juga diperkuat dengan kenyataan bahwa ratarata hasil belajar IPA kelas eksperimen lebih tinggi daripada kelas kontrol, artinya hasil belajar IPA yang meningkat pada kelas eksperimen diiringi atau berbanding lurus dengan hasil belajar IPA pada siswa.

Dengan demikian hasil pengujian hipotesis tersebut sekaligus membuktikan bahwa pengaruh Program Computer Assisted Instruction (CAI) bukan merupakan faktor kebetulan, tapi disebabkan oleh adanya perbedaan perlakuan pada masing-masing kelompok siswa. Program Computer Assisted Instruction (CAI) merupakan program komputer dalam pembelajaran IPA yang melibatkan siswa secara aktif dan akan sangat membantu keefektifan proses pembelajaran dalam penyampaian pesan dan isi pelajaran.

Selain membangkitkan motivasi dan minat siswa, Program Computer Assisted Instruction (CAI) juga dapat membantu siswa meningkatkan pemahaman, menyajikan data dengan menarik dan terpercaya, memudahkan penafsiran data, dan memadatkan informasi. Dapat dikemukakan bahwa penggunaan Program Computer Assisted Instruction (CAI) akan lebih berpengaruh pada hasil belajar siswa. Ini terbukti dengan rata-rata hasil belajar IPA pada kelas eksperimen lebih tinggi.

\section{Keterbatasan Penelitian}

Sebagai suatu karya ilmiah, penelitian ini telah dilakukan dengan sebaik mungkin sesuai prosedur penelitian ilmiah. Namun hasil yang diperoleh juga tidak luput dari kekurangan atau kelemahankelemahan akibat keterbatasan yang ada, sehingga menimbulkan hasil yang kurang sesuai seperti yang diharapkan. Keterbatasan-keterbatasan yang dapat diamati dan mungkin terjadi selama berlangsungnya penelitian, antara lain:

1. Penelitian dibatasi hanya pada materi sifat bahan dan perubahan benda.

2. Penelitian dibatasi hanya pada siswa SDN Mekarsari 06 Tambun Selatan sehingga generalisasinya terbatas pada populasi penelitian atau populasi lain yang memiliki karakteristik sama dengan karakteristik subjek penelitian. 
3. Instrumen yang digunakan dalam pengambilan data bukan satu-satunya instrumen yang dapat mengungkap seluruh aspek yang diteliti walaupun sebelumnya telah divalidasi dan diujicobakan.

\section{Kesimpulan}

Hasil penelitian dan analisis data yang diperoleh, yaitu pada kelas eksperimen saat pretest, didapat ratarata skor hasil belajar IPA sebesar 58,48 simpangan baku sebesar 7,86 sedangkan pretest pada kelas kontrol didapat rata-rata skor hasil belajar IPA sebesar 53,45, dengan simpangan baku sebesar 10,52. Sementara itu setelah diberikan perlakuan atau treatment pada salah satu kelompok, yaitu kelompok eksperimen dan diakhiri dengan pemberian post-tes, maka pada kelas eksperimen diperoleh rata-rata skor hasil belajar IPA sebesar 71,6 dengan simpangan baku sebesar 7,59, sedangkan hasil post-test pada kelas Kontrol diperoleh rata-rata skor hasil belajar IPA sebesar 63,28 dengan simpangan baku sebesar 10,38 dan varians sebesar 247, 96.

Berdasarkan hasil analisis dan paparan di atas diketahui bahwa hasil belajar dengan menggunakan Program Computer Assisted Instruction (CAI) lebih tinggi daripada yang belajar menggunakan media audio visual. Hal ini membuktikan bahwa pembelajaran dengan menggunakan Program Computer Assisted Instruction (CAI) merupakan salah satu alternatif yang dapat membantu menumbuhkan atau meningkatkan hasil belajar IPA siswa SD, yang selanjutnya akan berdampak pada keberhasilan belajar siswa.

Berdasarkan data yang peneliti peroleh, maka dapat diambil kesimpulan sebagai berikut:

1. Ada pengaruh penggunan program Computer Assisted Instruction (CAI) terhadap hasil belajar IPA tentang benda dan sifatnya.

2. Pembelajaran dengan menggunakan Program Computer Assisted Instruction (CAI) ini dapat membuat siswa lebih antusias, senang, percaya diri, sehingga menumbuhkan semangat siswa untuk belajar.

3. Pembelajaran dengan menggunakan Program Computer Assisted Instruction (CAI) dapat membantu mempertajam pesan yang disampaikan dengan kelebihannya menarik indera dan menarik minat, karena merupakan gabungan antara pandangan, suara dan gerakan.

\section{Implikasi}

Penggunaan Program Computer Assisted Instruction (CAI) dalam pembelajaran dapat dijadikan salah satu alternatif dalam hal penumbuhan atau peningkatan hasil belajar IPA siswa sekaligus memberikan manfaat langsung dalam proses Kegiatan Belajar Mengajar (KBM). Penggunaan Program Computer Assisted Instruction (CAI) dalam proses KBM dengan tepat, secara signifikan dapat berpengaruh terhadap peningkatan motivasi belajar IPA siswa. Pembelajaran dengan media komputer secara tepat akan memberikan pengalaman dan suasana yang menyenangkan ketika belajar. Sehingga dengan adanya pengalaman yang menyenangkan dapat menimbulkan atau menumbuhkan hasil belajar IPA siswa serta mengurangi image negatif selama ini tentang IPA dibenak siswa bahwa IPA pelajaran yang sulit karena terlalu banyak menghafal.

\section{Saran}

Berdasarkan penelitian yang telah penulis lakukan, maka akan dikemukakan beberapa saran sebagai berikut:

1. Sekolah diharapkan dapat menyediakan sarana dan prasarana untuk menunjang pembelajaran IPA.

2. Guru diharapkan menciptakan pembelajaran yang menyenangkan, tidak membosankan sehingga siswa lebih rileks dan tidak merasa tertekan yang mungkin selama ini dialami oleh siswa SD terutama ketika sedang belajar IPA.

3. Siswa diharapkan dapat memanfatkan Program Computer Asissted Intruction (CAI) dalam pembelajaran IPA.

4. Orang tua diharapkan dapat membantu proses pembelajaran IPA di luar jam sekolah.

5. Peneliti diharapkan dapat menambah jam terbang dalam penelitian agar penelitian menjadi lebih baik. 


\section{DAFTAR PUSTAKA}

Adri, Muhammad. $\quad$ Pemanfaatan Teknologi Informasi dan Komunikasi dalam Pengembangan Media

pembelajaran, http://directory.umm.ac.id/tik/adri-multimedia-pengajaran.pdf (diakses pada tanggal 29 Maret 2011)

Angkowo, R. Optimalisasi Media Pembelajaran. Jakarta: PT. Grasindo,2007.

Arsyad, Azhar. Media Pembelajaran. Jakarta: PT Raja Grafindo Persada, 1997.

Asri Budiningsih, C. Belajar dan Pembelajaran. Jakarta: Rineka Cipta, 2005.

Asy"eari, Muslichach. Penerapan Pendekatan Sains Teknologi Masyarakat Dalam Pembelajaran Sains di Sekolah Dasar .Depdiknas, 2006.

Baharudin dan Esa Nur Wahyuni. Teori Belajar dan Pembelajaran. Yogyakarta: Ar-Ruzz Media, 2007.

Chatib, Munif. Sekolahnya Manusia. Bandung: Kaifa PT Mizan Pustaka, 2009.

Depdiknas, Undang-undang Replublik Indonesia Nomor 20 Tahun 2003 tentang Sistem Pendidikan Nasional. Jakarta: Depdiknas, 2003

Ellysabeth "Pengaruh Penggunaan VCD Pembelajaran terhadap Hasil Belajar IPA Kelas IV Binaan V Kecamatan Kemayoran Jakarta Pusat", Skripsi (Jakarta: FIP, UNJ, 2010).

Evita et al. Psikologi Pendidikan. Jakarta: Lembaga Akta Mengajar, 2004.

G. Bitter, Gary dkk. Mathematics Methods For The Elementary And Middle School. Boston: Allyn and Bacon, 1989.

Hamalik, Oemar. Proses Belajar Mengajar . Jakarta: Bumi Aksara, 2001 http://abdussakir.wordpress.com/2009/01/25/pembelajaran-matematika-dengan-komputer/ (diakses pada

tanggal 14 Maret 2011)

http://www.papert.org/ (diakses pada tanggal 21 Maret 2011)

Imron, Ali. Belajar dan Pembelajaran .Jakarta: Pustaka Jaya, 1996.

Kadir. Statistik untuk Penelitian Ilmu-Ilmu Sosial. Jakarta: Rosemata Sampurna,2010.

Kountour, Ronny. Metode Pendidikan untuk Penulisan Skripsi dan Tesis: Penerbit

PPM,2005. M. Iskandar, Srini. Pendidikan Ilmu Pengetahuan Alam. Jakarta:Depdikbud,

2000. Mustolih, Multi Media dalam Pembelajaran. 2007

Nasution. Didaktik Azas-azas Mengajar . Bandung : Bumi Aksara, 1994.

Nasution, S., Berbagai Pendekatan dalam Proses Belajar dan Mengajar, Jakarta: Bumi Aksara. 2000

Percival Fred and Henry Elington, Teknologi Pendidikan.Jakarta: Erlangga, 1988.

Purwanto. Evaluasi Hasil Belajar. Yogyakarta: Pustaka Pelajar, 2009.

Qurtubi, Ahmad. Perencanaan Sistem Pengajaran . Tanggerang: PT. Bintang Harapan Sejahtera, 2009.

Rohani, Ahmad. Media Instruksional Edukatif. Jakarta: Rineka Cipta, 1997.

Sagala, Saiful. Konsep dan Makna Pembelajaran Bandung: Alfabetha, 2003.

Slameto. Belajar dan Faktor-Faktor yang Mempengaruhinya. Jakarta: Rineka Cipta, 2003.

Sudjana, Nana. Teori-Teori Belajar untuk Pengajaran. Jakarta: LPFEUI, 1992.

Sudjana, Nana. Penilaian Hasil Proses Belajar Mengajar .Bandung : PT Remaja Posdakarya.

Sugiyono, Metode Penelitian Pendidikan. Bandung: Alfabeta, 2008.

Sumaji. Pendidikan Sains yang Humanistis. Yogyakarta: Kanisius, 1998.

Sobry Sutikno, M. Belajar dan Pembelajaran .Bandung: Prospect, 2008.

Syah Darwyan,et. Al.Strategi Belajar Mengajar .Jakarta : Diadit Media, 2009.

Syah, Muhibbin. Psikologi Pendidikan: Suatu Pendekatan Baru. Bandung: Remaja Rosda Karya, 1995

Syah, Muhibin. Psikologi Belajar. Jakarta: PT Raja Grafindo,2003.

Syah, Muhibbin. Psikologi Pendidikan dengan Pendekatan Baru Jakarta: Rosda, 2008.

Syah, Muhibbin. Psikologi Belajar .Jakarta: PT. Raja Grafindo Persada, 2006. 
Yulaelawati, Ella. Kurikulum dan Pembelajaran: Filosofi, Teori dan Aplikasi Bandung : Pakar Raya, 2004.

Yulianto Nugroho Agung. Pembelajaran Berbantuan Komputer, Educational Technology Documents Universitas Negeri Surabaya, http://power-

point.tp.ac.id/?i=presentationtemplates:\%20classic\%20tutorial,\%20horton\%202000.ppt (diakses pada tanggal 30 Maret 2011).
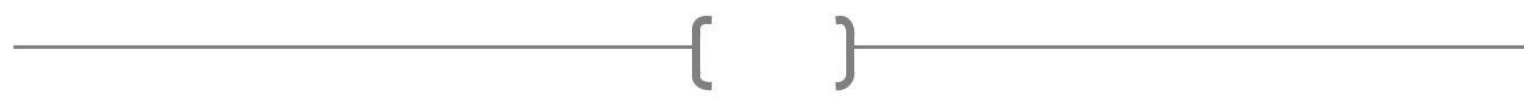